WHAT'S

HAPPENING

\title{
Innovations in Care Delivery
}

\section{From the Co-Editor}

\author{
Brian C. Callaghan, MD, MS
}

\section{Highlighted articles}

Innovations in Care Delivery strives to highlight articles that feature advances in care delivery in our Editor's Blog, Editor's Top 5 Recommended Reading, and Latest Articles sections. Periodically, we also include interviews with leaders in the field of health services research.

\section{Editor's blog}

Co-section editor Kevin Kerber wrote a blog titled "Caution in using pre/post research designs to inform changes in care delivery" in reference to the article by Chen et al. ${ }^{1}$ on the association between implementation of a code stroke system and poststroke epilepsy. Dr. Kerber highlighted the study design's limitations, namely the pre-post methodology, to emphasize that this study is just the first step in answering whether IV tissue plasminogen activator ( $\mathrm{tPA}$ ) can prevent poststroke epilepsy, such as when a code stroke system increases tPA utilization.

\section{Editor's top 5 recommended reading}

Neurology published an article titled "Racial disparities in neurologic health care access and utilization in the United States." ${ }^{2}$ The authors discovered that black and Hispanic participants are less likely to see an outpatient neurologist. Furthermore, black patients were more likely to have care provided in the emergency department and hospital and have higher inpatient costs. Further work is needed to understand why these differences exist and what interventions would work to reduce these disparities.

\section{Latest articles}

The American Academy of Neurology Institute's Quality and Safety Subcommittee, in partnership with the Society for Neuro-Oncology, published the neuro-oncology quality measurement set. ${ }^{3}$ The goal of this work was to identify gaps in neuro-oncology care that could lead to quality measures that would move the field forward. The group identified 5 measures including a multidisciplinary care plan, appropriate molecular testing, chemotherapy education and informed consent, intraoperative or postoperative MRI for gliomas, and prevention of venous thromboembolism following primary brain tumor surgery.

These 3 sections will keep neurologists up to date on innovations in care delivery within neurology and neurologic health services research.

\section{References}

1. Chen Z, Churilov L, Chen Z, et al. Association between implementation of a code stroke system and poststroke epilepsy. Neurology 2018;90:e1126-e1133.

2. Saadi A, Himmelstein DU, Woolhandler S, Mejia N. Racial disparities in neurologic health care access and utilization in the United States. Neurology 2017;88:2268-2275.

3. Jordan JT, Sanders AE, Armstrong T, et al. Quality improvement in neurology: neuro-oncology quality measurement set. Neurology 2018;90:652-658.

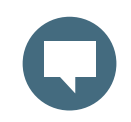

\section{Blog}

Read the Innovations in Care Delivery blog for timely posts by the editors and invited guests on Neurology ${ }^{\circledR}$ articles. NPub.org/icdblog 


\section{Neurology}

\section{What's Happening in Innovations in Care Delivery Neurology 2018;90;1062 \\ DOI 10.1212/WNL.0000000000005693}

This information is current as of June 4, 2018

\section{Updated Information \&} Services

References

Permissions \& Licensing

Reprints including high resolution figures, can be found at: http://n.neurology.org/content/90/23/1062.full

This article cites 3 articles, 3 of which you can access for free at: http://n.neurology.org/content/90/23/1062.full\#ref-list-1

Information about reproducing this article in parts (figures,tables) or in its entirety can be found online at:

http://www.neurology.org/about/about_the_journal\#permissions

Information about ordering reprints can be found online:

http://n.neurology.org/subscribers/advertise

Neurology ${ }^{\circledR}$ is the official journal of the American Academy of Neurology. Published continuously since 1951, it is now a weekly with 48 issues per year. Copyright (O 2018 American Academy of Neurology. All rights reserved. Print ISSN: 0028-3878. Online ISSN: 1526-632X.

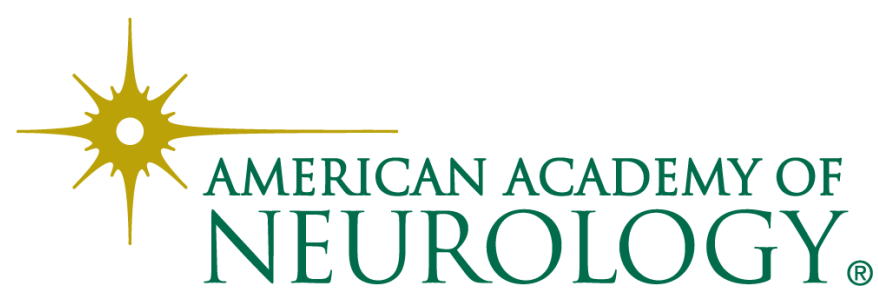

